\title{
The Countermeasures Assessment Towards Retirement Basic Savings Estimation Through the Mathematical Research
}

\author{
Hazimi Foziah, Puspa Liza Ghazali, Mustafa Mamat, Asyraf Afthanorhan, Wan Mohd Nazri \\ Wan Daud
}

\begin{abstract}
This paper focuses on the issues of ageing population which contributes towards inadequacy of retirement savings among Malaysian private sector workforce who mainly depends on Employee Provident Funds (EPF) to sustain their life during retirement age. However, the savings in the EPF fund cannot facilitate their expenditures for their entire life following the projected life expectancy of the age 75 years old, even most of retirees had spent all their retirement funds just within 3 to 5 years' period after reaching the age of retirement. The study attempted to look at the ideal basic savings by measuring the sustainability of the proposed amount to cover the expenditure costs during retirement age. However, the study found that the ideal basic savings amounted RM228,000 can only extended the financial coverage to the retirees up to the projected life expectancy if only if they are disciplined to make a periodical withdrawal of RM950 per month based of minimum monthly pension rate. However, the basic savings just only developed by considering the minimum monthly pension rate amounted RM950 and ignored the impact of inflation and profit gains through accumulative retirement funds in calculating the ideal basic savings. Thus, it would be better if the government and the related authorities have come up with the new basic savings by including those additional elements. It is important to gain a better idea towards the basic savings, which becomes the guideline for the prospect retirees in Malaysia.

Index Terms - Employee Provident Fund, ideal basic savings, inadequacy of retirement savings, mathematical modelling, retirement planning.
\end{abstract}

\section{INTRODUCTION}

All of the countries over the world have facing the phenomena of ageing population [1]-[3]. This trend is due to retirement by baby boomers which affects towards the increment of elderly share population of the countries [4]. Consequently, the ageing population has the impacts on future productivity as well as economic growth of the country [5], [6].

Furthermore, according to [7], all the country around the world are facing the phenomena of increment number of elderly person in their population, which in turn impacts all society sectors likes labor and financial markets, good and

Revised Manuscript Received on July 10, 2019.

Hazimi Foziah, Faculty of Economics and Management Sciences, Universiti Sultan Zainal Abidin, Terengganu, Malaysia.

Puspa Liza Ghazali, Faculty of Economics and Management Sciences, Universiti Sultan Zainal Abidin, Terengganu, Malaysia

Mustafa Mamat, Faculty of Informatic and Computing, Universiti Sultan Zainal Abidin, Terengganu, Malaysia

Asyraf Afthanorhan, Faculty of Economics and Managemen Sciences, Universiti Sultan Zainal Abidin, Terengganu, Malaysia

Wan Mohd Nazri Wan Daud, Faculty of Economics and Management Sciences, Universiti Sultan Zainal Abidin, Terengganu, Malaysia. services such as home, transportation and social protection, and changes in the family structures.

This rapid ageing population also affects Malaysia country, whenever in [8] has reported that people at the age 65 years in Malaysia are estimated to live for 15 and 17 years with respect to the male and female gender. Moreover, the total elderly population in Malaysia at the age 65 years and above showed an upward trend through the years, which indicated at $5.6 \%$ to $5.8 \%$ in years 2014 and 2015 respectively, and expected to jump for $6 \%$ in 2016 in which nearly reached $7 \%$ of total population of elderly for ageing country status [9].

Regarding this scenario, having a good retirement savings is a must to ensure the financial protection during the golden age. Generally, retirement system has been classified into three tiers system, known as social security, employmentbased pensions, and individual savings, in which had been practiced by many countries over the world [10] Nevertheless, the major retirement system being adopted in Malaysia can be only classified as two tier pension system, which consists of Employee Provident Funds (EPF) and pension's scheme for the government servant.

The former system is facilitating for those in private sector workforce which basically stands for employmentbased pensions defined contribution system, while the latter is also under employment-based pension but with different platform of defined contribution system. Although, Malaysia as a developing country, it is still left behind by other country in the same class. As we can see Chile, Brazil China, and India are listed in a top 20 countries have a good retirement system in the world [11]

The main concern here is EPF have reported in 2016 that 70 per cent of EPF members who will be retired in the next year, have accumulated their retirement savings below than RM50,000 in their EPF account [12]. In addition to this, 50 per cent of retirees have depleted their retirement savings for 3 to 5 years [12]-[14]. The report reveals an alarming problem of having inadequate retirement savings among Malaysian elderly.

Moreover, this indicates the serious problem with financial management among Malaysian people, especially their awareness of future retirement savings and how to manage their savings in order to sustain their entire life after getting lump sum payment from EPF [15], [16]. 


\section{THE COUNTERMEASURES ASSESSMENT TOWARDS RETIREMENT BASIC SAVINGS ESTIMATION THROUGH THE MATHEMATICAL RESEARCH}

\section{LITERATURE REVIEW}

In conjunction to this, in [17] asserted in their study that some of retirees were still working because of financial needs and only a small fraction of them choose to keep work due to their self-achievement and fulfillment. Basically, the retirees subject to the retirement hazards like's costs of healthcare, presuming a longer working life, misjudging how long one spouse will live, demographic change and consequences to retirement [18].

Regards on healthcare costs issue, in [15] mentioned that elderly people aged 60 and above require greater medical attention by visiting medical and healthcare centers, six times a year, on an average. Thus, it would further imply heavier financial burden with rising medication and healthcare costs. Moreover, to make this worse, Malaysian people are still lack of awareness towards their future retirement planning [23].

As a record released by [22], the overall index of Malaysian retirement system is at $\mathrm{C}$ grade which considering fair but still has major risk and shortcoming to be improved or else the system will not be efficient enough especially for long term sustainability. Moreover, in [22] added that in term of adequacy of the retirement system which covers for benefits, savings, benefit design, tax support and growth assets, Malaysia is placed at grade D and left behind others developing countries likes Brazil, Chile, China and Poland in having a better adequacy of retirement wealth.

In addition to this, retirement system in Malaysia should have incorporated multiple tiers system, so that full replacement of retirement income can be achieved [17]. In [26] has suggested to reconstruction the Malaysia's pension system through a combination of parametric and systemic reforms of individual schemes by the EPF.

As a mainstream retirement scheme in Malaysia, EPF needs to reform the country's central pension pillar from merely retirement savings investment fund to a fully-fledged pension fund, in which at least offers some minimum annuities, and if possible change to the non-defined contribution scheme [27]. Furthermore, in [28] had claimed that a lump sum benefit payment of the EPF become more preference by the members rather than opt for a phased withdrawal basis benefit, and a lump sum basis option has no longer represent the best option for income security of the elderly people.

In this situation, the traditional lump sum payment of retirement benefit should be revised back since Malaysian retirees are lack of financial management to allocate their money in order to sustain their financial position for entire life [32]. It would be better to propose an annuity based scheme as a mandatory form of retirement benefit, since it was a positive feedback by the Malaysian public towards the monthly withdrawal instead of lump-sum form of retirement benefit payment [33].

Indeed, in [15] revealed that the adequacy of savings and retirement resources were at serious problems among the low-income and middle-income earners in Malaysia. The retirement incomes adequacy became a major problem is due to people in Malaysia still lack awareness to think about their retirement saving preparedness [23]. Moreover, in the case of EPF, their members were given permissible for pre- withdrawal provisions and as a result failed to maintain high investment returns [24].

In fact, the minimum of wealth-need ratio projections of 69 per cent to be adequately prepared for retirement [25]. It is clearly depicting that Malaysian nowadays facing a serious problem with inadequacy of retirement wealth, which is before becoming an ageing country.

Addressing the issues of inadequacy retirement wealth and lack of financial preparedness among Malaysian people towards retirement, the ideal for basic saving has been revised and become effective in the $1^{\text {st }}$ January 2017 with the increment from RM196,800 to RM228,000 which believed can be consumed within 20 years period [19]. The increasing trend of the ideal basic savings amount depicts that the requirement for retirement expenditure would become costlier for retirees in future. It is due to the impact of time value of money. Since, the retirement basically takes long term period to reach, it may significantly impact the total amount of basic savings due to the national inflation and interest gains.

Therefore, it is responsibility for this study with the aims of examining the proposed minimum ideal of basic savings for Malaysian people to have before retired in order to sustain their life during retirement, and becomes a guideline to public as a minimum financial requirement before getting retired.

\section{METHODOLOGY}

Based on the ideal basic saving of RM228,000, the study apply the minimum amount of government pension amounted to RM950 per month as mentioned in the Malaysian 2016 Budget [20] to measure the sustainability of the proposed ideal basic savings to provide the financial coverage up to life expectancy of 75 years old.

Then study can generate the simulation result of retirees' expenditure based on the given funds in measuring the sustaining the monthly payment of annuity period. The general simulation elements can be referred in Table 1 .

Table 1: General simulation estimation of ideal basic saving's annual expenditure

$$
\begin{aligned}
& \text { where } \\
& \mathrm{N}=\text { Number of year } \\
& \mathrm{A}=\text { Age of EPF retiree } \\
& \mathrm{C}=\text { Annual consumption } \\
& \mathrm{BS}=\text { Retirement fund balance from total } \\
& \text { accumulated savings } \\
& =\text { RM 228,000-RM 11,400 = RM 216,000 }
\end{aligned}
$$

The elements of $N, A, C$, and $B S$ can be generated through mathematical formulations are derived as in the Table 2 . 
Table 2: Mathematical formulation in generating the simulation result

\begin{tabular}{|c|c|l|}
\hline Element & & \multicolumn{1}{|c|}{ Formula } \\
\hline$C$ & $=$ & Monthly consumption $\mathrm{x} \mathrm{12}$ \\
\hline & & RM950 x 12= RM11,400 \\
\hline$B S$ & $=$ & $\begin{array}{l}\text { Previous retirement fund balance-annual } \\
\text { consumption }\end{array}$ \\
\hline & & $B S_{n-1}-C$ \\
\hline$B S_{I}$ & $=$ & $\mathrm{RM} 228,000-\mathrm{RM} 11,400$ \\
\hline & $=$ & $\mathrm{RM} 216,000$ \\
\hline
\end{tabular}

\section{RESULTS AND DISCUSSION}

The ideal amount of basic savings can be rationalized by translating it into the Table 3.

Table 3: Estimation of ideal basic saving's annual

\begin{tabular}{|c|c|c|c|}
\hline $\mathrm{N}$ & $\mathrm{A}$ & $\mathrm{C}$ & $\mathrm{BS}$ \\
\hline 0 & 55 & 11,400 & 228,000 \\
\hline 1 & 56 & 11,400 & 216,600 \\
\hline 2 & 57 & 11,400 & 205,200 \\
\hline 3 & 58 & 11,400 & 193,800 \\
\hline 4 & 59 & 11,400 & 182,400 \\
\hline 5 & 60 & 11,400 & 171,000 \\
\hline 6 & 61 & 11,400 & 159,600 \\
\hline 7 & 62 & 11,400 & 148,200 \\
\hline 8 & 63 & 11,400 & 136,800 \\
\hline 9 & 64 & 11,400 & 125,400 \\
\hline 10 & 65 & 11,400 & 114,000 \\
\hline 11 & 66 & 11,400 & 102,600 \\
\hline 12 & 67 & 11,400 & 91,200 \\
\hline 13 & 68 & 11,400 & 79,800 \\
\hline 14 & 69 & 11,400 & 68,400 \\
\hline 15 & 70 & 11,400 & 57,000 \\
\hline 16 & 71 & 11,400 & 45,600 \\
\hline 17 & 72 & 11,400 & 34,200 \\
\hline 18 & 73 & 11,400 & 22,800 \\
\hline 19 & 74 & 11,400 & 11,400 \\
\hline 20 & 75 & 11,400 & - \\
\hline
\end{tabular}

The above figure seemingly good indicator if a person can successful accumulate the retirement savings up to basic savings amount, as it is can sustain the minimum pension consumption of RM950 for the next 20 years' period, which is equivalent to the current Malaysian life expectancy of 75 years old. However, not all retirees would have accumulated amount of RM 228,000 in their EPF account. In fact, it is revealed that 70 per cent of the EPF members who going to retire in year 2016, have below than RM50,000.

Ironically, calculation of basic savings is rather a straightforward calculation without considering other factors. In essence, the minimum consumption of RM950 is actually not the same value gains for the next 10 years or even 20 years or more. It is because one of the principles of finance concerned about time value of money. The real value should be decreasing over time. The longer the passing time, the more it will depreciate in value. The calculation however should consider the inflation rate in order to get the better result. By considering the inflation expenditure

factor in the estimation of retirement wealth, it is surely decreased the current value, and this will make almost all of the retirees living under poverty as the poverty line income is at RM 930 per month [21].

\section{CONCLUSION}

In conclusion, the revised ideal basic savings of RM228,000 has enough to sustain the retirees financial position up to their life expectancy. This only possible if they are discipline and willing to withdraw their retirement through a monthly basis like pension annuity instead of lump sum basis. However, the study also found that, the result has no realistic as one of the importance principle of finance, known as time value of money was ignored in the estimation. Since, the retirement planning deemed as long term basis investment or savings, the value of money is vital to be considered. Hence, the elements that relate in this context were inflation rate and also the profit gains from the total savings or investment of the retirement funds.

Thus, as Malaysia will be becoming an ageing country, it would be better to get prepared with longevity risk and its implication towards financial aspect, prevention is better than cure. In light of the problem of inadequacy retirement wealth, lack of financial savings among citizens, and the growth of elderly population in future, Malaysia should not delay their improvement in retirement system. Therefore, it can be intriguing study to investigate the existing retirement system in Malaysia in order to formulate a betterment and enhance the system.

\section{ACKNOWLEDGMENT}

The authors thank the referees for their contributions and also grateful to the Malaysian government and Universiti Sultan Zainal Abidin for funding this research under the Fundamental Research Grant Scheme (FRGS/1/2017/STG06/Unisza/01/1).

\section{REFERENCES}

1. World Health Organization, Why Population Aging Matters: A Global Perspective. Washington DC: National Institute of Health, 2007.

2. A. Crampton, "Global aging: Emerging challenges," The Pardee Papers, 6, 2009, pp. 1-25.

3. W. He, D. Goodkind, and P. U. S. Kowal, Census Bureau, International Population Reports, P95/16-1, An aging world: 2015. Washington DC: U.S. Government Publishing Office, 2016.

4. D. L. Rogers, E. Toder, and L. Jones, "Economic consequences of an aging population," The Retirement Project, Urban Institute, 6, 2000, pp. 1-24.

5. A. Cheng, The consequences of an ageing population for Australia's future productivity and economic growth, and the associated economic policies challenges. RBA Economics Competition, University of New South Wales, 2007.

6. K. Lisenkova, and K. Bornukova, "Effects of population ageing on the pension system in Belarus," Baltic Journal of Economics, 17(2), 2017, pp. 103-118.

7. Department of Economic and Social Affairs, Population Division, World Population Ageing 2015. New York: United Nations. 


\section{THE COUNTERMEASURES ASSESSMENT TOWARDS RETIREMENT BASIC SAVINGS ESTIMATION THROUGH THE MATHEMATICAL RESEARCH}

8. Department of Statistics, Current population estimates. Putrajaya: Department of Statistics Malaysia, 2015.

9. Department of Statistics, Monthly Statistical Bulletin. Putrajaya: Department of Statistics Malaysia, 2016

10. K. L. Moore, "An overview of the US retirement income security system and the principles and values it reflects," Company Labor Law and Policy Journal, 33(5), 2011, pp. 548.

11. Mercer, Melbourne Mercer Global Pension Index. Victoria: Australian Center for Financial Studies, 2015.

12. Employees Provident Fund, Retirement advisory service. Available: http://www.kwsp.gov.my/ras/index.html.

13. S. Khan, O. Tan, N. Khan, and R. G. Vergara, "Strengthening social safety net for older people in Malaysia," Journal of Southeast Asian Research, 2017, pp. 1-10.

14. S. K. Poh, "A retirement shipwreck on the horizon?" Financial Planning Association of Malaysia-4E Journal, 2(15), 2015, pp. 7-11.

15. J. Y. Folk, L. S. Beh, and D. L. Baranovich, "Financial education: Determinant of retirement planning in Malaysia," Journal of Business Management and Economics, 3(2), 2012, pp. 69-78.

16. N. H. M. Foziah, P. L. Ghazali, M. Mamat, F. Salleh, and S. B. Mohamed, "Mathematical analysis of retirement income benefit based on annuitization approach," International Journal of Academic Research in Business and Social Sciences, 7(7), 2017, pp. 865-871.

17. F. S. Ong, and T. A. Hamid, Social protection in MalaysiaCurrent state and challenges. Economic Research Institute for ASEAN and East Asia (ERIA) Project on Social Protection, 2010.

18. Z. Shafii, Z. Yusoff, and S. M. Noh, Islamic financial planning and wealth management. Kuala Lumpur: IBFIM, 2013.

19. Employees Provident Fund, Annual report 2016. Kuala Lumpur: Employees Provident Fund, 2016.

20. Ministry of Finance Malaysia, 2016 budget. Putrajaya: Percetakan Nasional Malaysia Berhad, 2015.

21. N. A. Manap, Z. Zakaria, and R. Hassan, "Investigation of poverty indicators for designing case representation to determine urban poverty," International Journal of Advances in Soft Computing and Its Applications, 9(2), 2017, pp. 91106.

22. Mercer, Melbourne Mercer Global Pension Index. Melbourne: Australia Centre for Financial Studies, 2016.

23. D. Ibrahim, Z. M. Isa, and N. Ali, "Malaysian savings behavior towards retirement planning," International Conference on Economics Marketing and Management, 2012, pp. 102-105.

24. R. Ja'afar, and K. J. Daly, "Reviewing the financial soundness of the Malaysia's Employees Provident Fund," International Conference on Economics, Management and Corporate Social Responsibility, 2016, pp. 14-18.

25. R. I. Alaudin, N. Ismail, and Z. Isa, "Projection of retirement adequacy using wealth-need ratio: Optimistic and pessimistic scenarios," International Journal of Social Science and Humanity, 6(5), 2016, pp. 332-335.

26. D. Park, Pension Systems and Old-Age Income Support in East and Southeast Asia: Overview and Reform Directions. Abingdon: Routledge, 2012.

27. R. Holzmann, Old-age financial protection in Malaysia: Challenges and options. 2014, Available: https://openknowledge.worldbank.org/bitstream/handle/10986 /21038/927250NWP014250Box385377B00PUBLIC0.pdf?seq uence $=1$.

28. R. Beattie, "Pension systems and prospects in Asia and the Pacific," International Social Security Review, 51(3), 1998, pp. 63-87.

29. National Human Resource Centre, Home. Available: http://www.nhrc.com.my/web/10179/446.
30. F. Vettese, Calculating investment returns: Actuarially speaking, 6 per cent is a good rule of thumb. 2013, Available: http://business.financialpost.com/personal-

finance/retirement/calculating-investment-returns-actuariallyspeaking-6-is-a-good-rule-of-thumb.

31. Statista, Malaysia: Inflation rate from 2012 to 2022 (compared to the previous year). 2018, Available: https://www.statista.com/statistics/319033/inflation-rate-inmalaysia/.

32. N. H. M. Foziah, P. L. Ghazali, M. Mamat, F. Salleh, D. A. Guci, S. A. S. Jaaffar, M. S. Mahmud, and A. S. Yazid, "Viability of annuity-based option as retirement form of benefit among EPF retirees," International Journal of Engineering and Technology, 7(3.28), 2018, pp. 191-193.

33. N. H. M. Foziah, P. L. Ghazali, M. Mamat, F. Salleh, D. A. Guci, S. A. S. Jaaffar, A. Afthanorhan, L. Omar, and A. S. Yazid, "Analysis of private sector retiree's decision towards EPF retirement benefit of annuity-based option," International Journal of Engineering \& Technology, 7(3.28), 2018, pp. 185188. 